\title{
FceRI-mediated mast cell response is modulated by TLR2 and TLR4 ligation
}

\author{
ALEKSANDRA SŁODKA, EWA BRZEZIŃSKA-BEASZCZYK
}

Department of Experimental Immunology, Medical University of Łódź, Poland

\begin{abstract}
It is well documented that mast cells express both FcERI and Toll-like receptors (TLRs). It is also suggested that subsequent/simultaneous mast cell activation via TLR and FcERI may affect these cells activity. In the present study we examined the influence of lipoarabinomannan (LAM), that is TLR2 ligand, and lipopolysaccharide (LPS), that is TLR4 agonist, on mast cell degranulation and preformed mediator release and cysteinyl leukotriene (cysLT) generation mediated by FcERI aggregation. Our experiments were performed on native rat peritoneal mast cells and on peritoneal mast cells pre-coated in vitro with IgE. We found that neither LAM-nor LPS-priming modified degranulation of native mast cells. Under the same experimental conditions LAM-induced TLR2 ligation caused statistically significant $(p<0.01)$ decrease in Fc\&RI-mediated histamine release from IgE-coated mast cells. Moreover, we noticed that simultaneous stimulation via TLR4 or TLR2 and FCERI resulted in synergistic amplification of cysLT generation from IgE-coated mast cells and, to a lesser extent, from native mast cells. These observations might be a clue to understanding the mechanistic basis of allergic disease exacerbation upon coexisting infections.
\end{abstract}

Key words: mast cells, Toll-like receptors, bacterial antigens, allergic diseases, histamine, leukotrienes.

(Centr Eur J Immunol 2013; 38 (1): 23-28)

\section{Introduction}

The high affinity receptor for immunoglobulin $\mathrm{E}$ (FceRI) is expressed on the surface of mast cells. These cells are the principal effector cells in the classical type I hypersensitivity reaction which underlies the pathomechanism of IgE-dependent allergic diseases. In response to FceRI cross-linking by specific IgE and antigen (allergen) various cascade signaling downstreams are activated leading to mast cell degranulation, arachidonic acid metabolite generation as well as synthesis of chemokines, cytokines and growth factors [1, 2].

It is now well documented that Toll-like receptors (TLRs), the pattern recognition receptors for pathogen components, are constitutively and highly expressed on the mast cells $[3,4]$. TLR ligation by its agonists induces the highly selective mast cell response. A number of studies have indicated that neither TLR2 nor TLR4 stimulation resulted in mast cell degranulation and preformed mediator release [5-10] but it induces synthesis of newly generated lipid mediators, including cysteinyl leukotrienes (cysLTs) [5, 7-13]. TLR2 and TLR4 ligation can activate mast cells to synthesize many different cytokines and chemokines, as well [5, 7, 14-17].

Taking into account that both TLR2 and TLR4 ligation as well as FceRI-mediated stimulation lead to mast cell activation, it may be assumed that to some extent subsequent or simultaneous stimulation via TLR and via FceRI may affect mast cell response. Current knowledge about the influence of TLR/FceRI network on mast cell activation is limited and the results of latest research are often ambiguous. In the present study we scheduled to examine the effect of lipoarabinomannan (LAM), that is TLR2 ligand, and lipopolysaccharide (LPS), that is TLR4 agonist, on mast cell preformed mediator release and cysLT generation mediated by FceRI aggregation with IgE and anti-IgE. Considering that FceRI-IgE complex formation induces upregulation of FceRI expression [18-21], which in turn may significantly alter mast cell sensitivity and releasability, we

Correspondence: Ewa Brzezińska-Błaszczyk, Department of Experimental Immunology, Medical University of Łódź, Pomorska 251, 92-213 Łódź, Poland, tel./fax +48 4267573 06, e-mail: ewab@csk.umed.lodz.pl 
conducted our research using native as well as mast cells previously coated with IgE.

\section{Material and methods}

\section{Reagents}

Dulbecco's Modified Eagle's Medium (DMEM), Hank's balanced salt solution (HBSS), sodium bicarbonate, fetal calf serum (FCS), gentamicin and glutamine were purchased from GIBCO, Life Technologies (Gaithersburg, MD, USA). Lipopolysaccharide from Escherichia coli O55:B5, $\mathrm{NaCl}, \mathrm{KCl}, \mathrm{MgCl}_{2}, \mathrm{CaCl}_{2}$, 2-hydroxyethylpiperazine-N'-ethanesulphonic acid (HEPES), $\mathrm{NaOH}$, glucose, $\mathrm{HCl}, o$-phthaldehyde (OPT), Percoll, trypan blue, toluidine blue and bovine serum albumin (BSA) were obtained from Sigma-Aldrich (St. Louis, MO, USA). Lipoarabinomannan from Mycobacterium smegmatis was purchased from InvivoGen (San Diego, CA, USA) and rat myeloma IgE was obtained from Invitrogen, Life Technologies (Gaithersburg, MD, USA). Mouse anti-rat IgE was purchased from AbD Serotec (Oxford, United Kingdom), goat IgG isotype control was obtained from Abcam Inc. (Cambridge, MA, USA), cysLT immunoassay kit was purchased from Cayman Chemical (Ann Arbor, MI, USA), and goat IgG antibodies blocking TLR2 were purchased from Santa Cruz Biotechnology (Santa Cruz, CA, USA).

\section{Isolation of mast cells}

Mast cells were obtained from peritoneal cavities of female albino Wistar rats weighing 200-250 g by lavage with $50 \mathrm{ml}$ of $1 \%$ HBSS supplemented with $0.015 \%$ sodium bicarbonate. After abdominal massage ( $90 \mathrm{~s})$, the cell suspension was removed from the peritoneal cavity, centrifuged $\left(1200 \mathrm{rpm}, 5 \mathrm{~min}, 20^{\circ} \mathrm{C}\right)$, and washed twice in complete (c)DMEM containing DMEM supplemented with $10 \% \mathrm{FCS}, 10 \mu \mathrm{g} / \mathrm{ml}$ gentamicin, and $2 \mathrm{mM}$ glutamine (1200 rpm, $5 \mathrm{~min}, 20^{\circ} \mathrm{C}$ ). To prepare purified mast cells, peritoneal cells were resuspended in $72.5 \%$ isotonic Percoll solution and centrifuged ( $1500 \mathrm{rpm}, 20 \mathrm{~min}, 20^{\circ} \mathrm{C}$ ). Isolated mast cells were washed twice in cDMEM by centrifugation, counted and resuspended in an appropriate volume of medium for rat mast cells containing $137 \mathrm{mM}$ $\mathrm{NaCl}, 2.7 \mathrm{mM} \mathrm{KCl}, 1 \mathrm{mM} \mathrm{MgCl} 2,1 \mathrm{mM} \mathrm{CaCl}_{2}, 10 \mathrm{mM}$ HEPES buffer, $5.6 \mathrm{mM}$ glucose, and $1 \mathrm{mg} / \mathrm{ml} \mathrm{BSA} \mathrm{(pH} \mathrm{of}$ the medium was adjusted to 6.9) to obtain a mast cell concentration of $1.5 \times 10^{6}$ cells $/ \mathrm{ml}$. The mast cells were prepared with purity $>98 \%$, as determined by metachromatic staining with toluidine blue.

\section{Histamine release assay}

Native or IgE-coated mast cells (i.e. cells preincubated with $1 \mu \mathrm{g} / \mathrm{ml}$ of $\mathrm{IgE}$ for $60 \mathrm{~min}$ at $37^{\circ} \mathrm{C}$ and then washed by centrifugation) were incubated with LAM or LPS (bacterial antigens at final concentrations of $0.1 \mu \mathrm{g} / \mathrm{ml}$ or $10 \mu \mathrm{g} / \mathrm{ml}$ ) or medium alone for $60 \mathrm{~min}$ at $37^{\circ} \mathrm{C}$ in a water bath with constant stirring. Mast cells were washed by centrifugation, suspended in medium and incubated with anti-IgE at final concentration of $5 \mu \mathrm{g} / \mathrm{ml}$ or medium alone for $30 \mathrm{~min}$ at $37^{\circ} \mathrm{C}$. The reaction was stopped by adding $1.9 \mathrm{ml}$ of cold medium and then the cell suspensions were centrifuged (1200 rpm, $5 \mathrm{~min}, 4^{\circ} \mathrm{C}$ ). The supernatants were decanted into separate tubes and a total of $2 \mathrm{ml}$ of distilled water was added to each tube with cell pellet. All samples were acidified with $3 \mathrm{~N}$ HCL. The histamine content was determined in both cell pellets (residual histamine) and supernatants (released histamine) by spectrofluorometric method using OPT. Histamine release was expressed as a percentage of the total cellular content of the amine after correction for the spontaneous release indicated in controls.

For time-course experiments IgE-coated mast cells were incubated with bacterial antigen at final concentration of $10 \mu \mathrm{g} / \mathrm{ml}$ for $1,3,5,10,20,40$ or $60 \mathrm{~min}$ and next treated as described above.

To determine the specificity of bacterial antigen effect on anti-IgE-induced histamine release in some experiments, before main procedure, mast cells were preincubated with anti-TLR2 antibodies or goat $\mathrm{IgG}$ as a isotype control at final concentration of $40 \mu \mathrm{g} / \mathrm{ml}$ for $15 \mathrm{~min}$ at $37^{\circ} \mathrm{C}$. After that, mast cells were washed twice, resuspended in medium and treated as described above.

\section{CysLT release assay}

Native or IgE-coated mast cells were suspended in medium and incubated with LAM (final concentration of $2.5 \mu \mathrm{g} / \mathrm{ml}$ ) or LPS (final concentration of $0.5 \mu \mathrm{g} / \mathrm{ml}$ ) in the presence or absence of anti-IgE (final concentration of $5 \mu \mathrm{g} / \mathrm{ml}$ ) in a water bath with constant stirring for $60 \mathrm{~min}$ at $37^{\circ} \mathrm{C}$. At the same time, mast cells were incubated with anti-IgE alone, LAM alone, LPS alone, calcium ionophore A23187 at final concentration of $5 \mu \mathrm{g} / \mathrm{ml}$ (positive control), or medium alone (spontaneous cysLT release). The supernatans were collected by centrifugation $(1200 \mathrm{rpm}, 5 \mathrm{~min}$, $20^{\circ} \mathrm{C}$ ) and analyzed by an ELISA commercial kit that detected $\mathrm{LTC}_{4}$ and its degradation products $\mathrm{LTD}_{4}$ and $\mathrm{LTE}_{4}$. The sensitivity of this assay was $<13 \mathrm{pg} / \mathrm{ml}$.

\section{Statistical analysis}

Statistical parameters included mean value \pm standard error of the mean (SEM), and Student's $t$-test for "small groups". Values of $p<0.05$ were considered statistically significant.

\section{Results}

\section{The effect of bacterial antigens on mast cell anti-IgE-induced histamine release}

We first examined the effect of priming with TLR2 ligand, that is LAM, on anti-IgE-induced degranulation and 


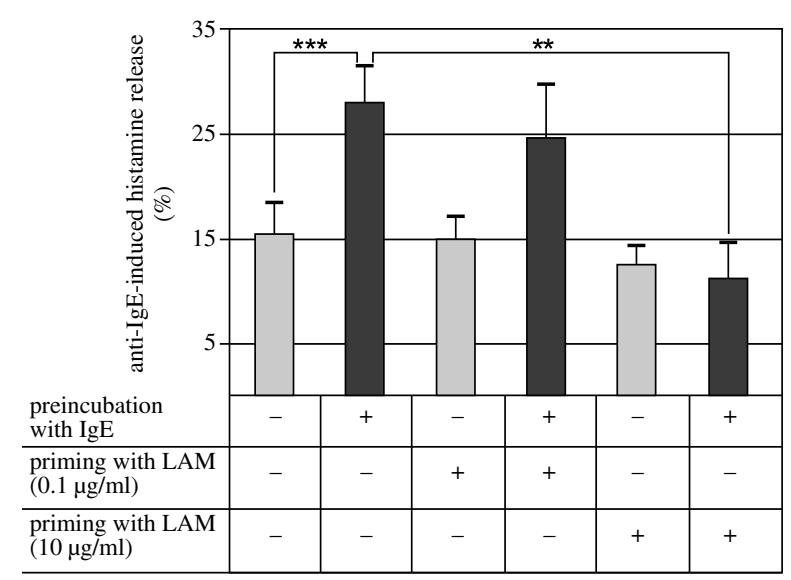

$* * p<0.01, * * * p<0.001$

Fig. 1. Effect of LAM priming on anti-IgE-induced histamine release from native (white bars) and IgE-coated (black bars) mast cells. Results are expressed as the mean \pm SEM of three independent experiments and each experiment was carried out in duplicate $(n=6)$

histamine release from mast cells. As shown in Fig. 1, pretreatment of mast cells with LAM did not affect histamine release induced by anti-IgE from native mast cells. However, priming with LAM at concentration of $10 \mu \mathrm{g} / \mathrm{ml}$ caused statistically significant $(p<0.01)$ decrease in histamine release from IgE-coated mast cells in response to antiIgE stimulation. Under the same experimental conditions priming with LPS, that is TLR4 ligand, used at concentrations of $0.1 \mu \mathrm{g} / \mathrm{ml}$ and $10 \mu \mathrm{g} / \mathrm{ml}$ did not influence anti- $\mathrm{IgE}$ induced histamine release from native as well as IgE-coated mast cells (Fig. 2). It should be underlined, that neither LAM nor LPS directly activated mast cells to degranulation and histamine release (data not shown).

We examined the effect of LAM-priming time on histamine release from IgE-coated mast cells in response to anti-IgE stimulation, as well. We noticed that statistically significant $(p<0.05)$ decrease of anti-IgE-induced histamine release was observed after 40 min preincubation with LAM. After 60 min of LAM-pretreatment anti-IgE-induced release of histamine decreased from $23 \%$ to $11 \%(p<0.01)$ (Fig. 3). We also noticed that blocking TLR2 with related antibodies, prior to IgE-coated mast cell priming with LAM (at concentration of $10 \mu \mathrm{g} / \mathrm{ml}$ ) and anti-IgE challenge, strongly and statistically significant abolished LAM-induced suppressive effect exerted on IgE-mediated histamine secretion (data not shown).

\section{The effect of co-stimulation with bacterial antigens and anti-IgE on mast cell cysLT generation}

Next we investigated whether simultaneous activation of both native and IgE-coated mast cells via TLR2 or TLR4 and FceRI affects cysLT generation and release. The results

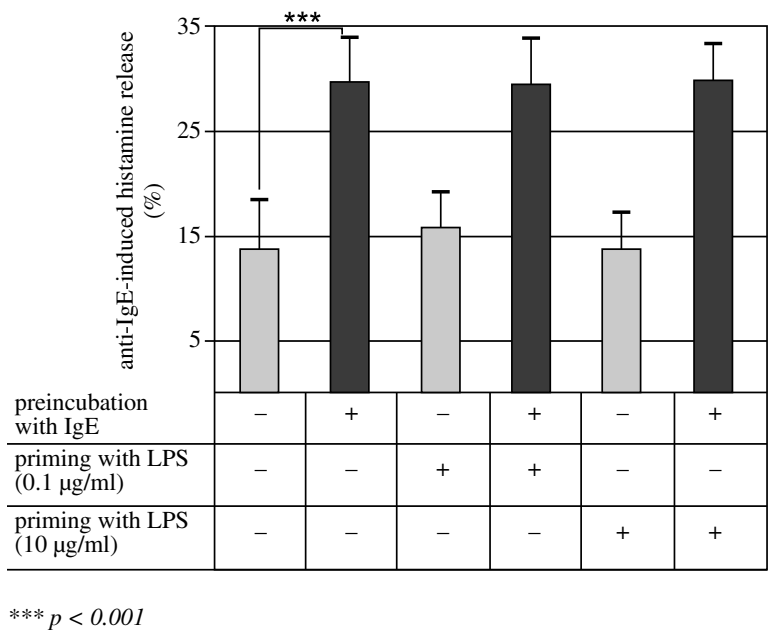

Fig. 2. Effect of LPS priming on anti-IgE-induced histamine release from native (white bars) and IgE-coated (black bars) mast cells. Results are presented as the mean \pm SEM of three independent experiments and each experiment was carried out in duplicate $(n=6)$

of these experiments are presented in Fig. 4. Both LAM and LPS directly activated native and IgE-coated mast cells to cysLT synthesis and release. The combination of LAM with anti-IgE markedly and statistically significant $(\mathrm{p}<0.05)$ augmented cysLT release from native mast cells. Also, simultaneous activation of native mast cells by LPS and anti-IgE caused statistically significant $(\mathrm{p}<0.05)$ increase in cysLT generation, as compared with anti-IgE-mediated generation by itself (Fig. 4A). Lipoarabinomannan or LPS

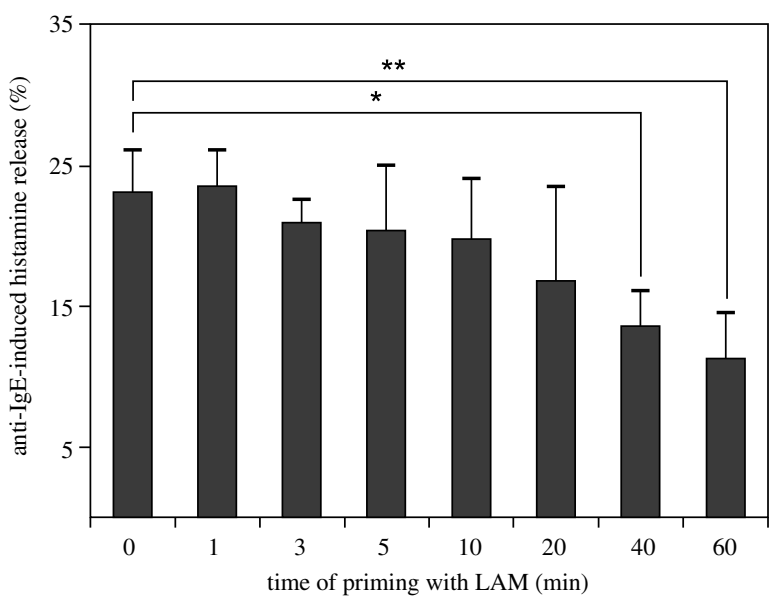

$* p<0.05, * * p<0.01$

Fig. 3. Time-course of LAM-priming on anti-IgE-induced histamine release from IgE-coated mast cells. LAM was used at final concentration of $10 \mu \mathrm{g} / \mathrm{ml}$. Results are presented as the mean \pm SEM of three independent experiments and each experiment was carried out in duplicate $(n=6)$ 
A native, IgE-uncoated mast cells

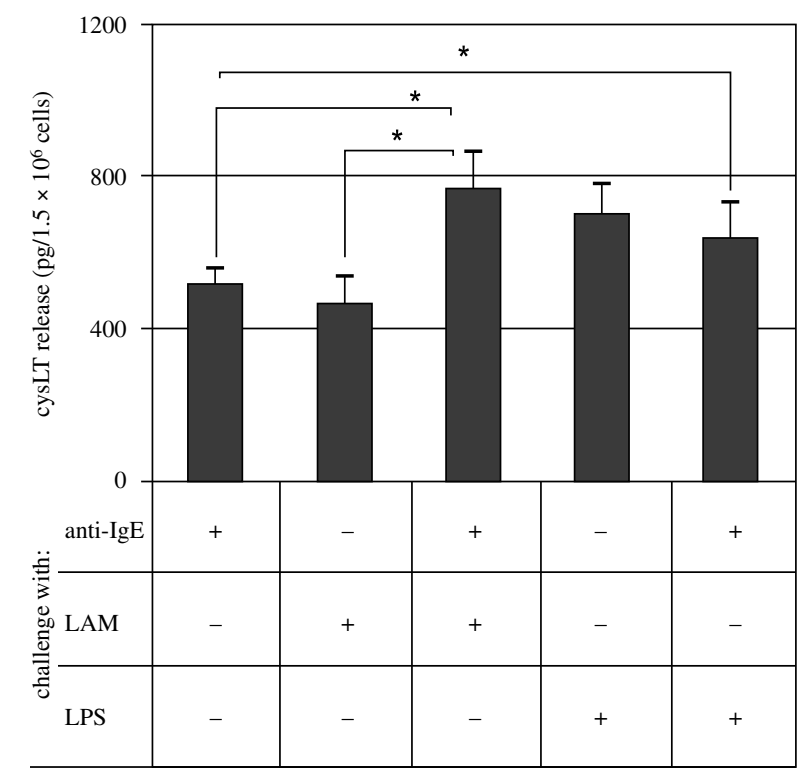

B IgE-coated mast cells

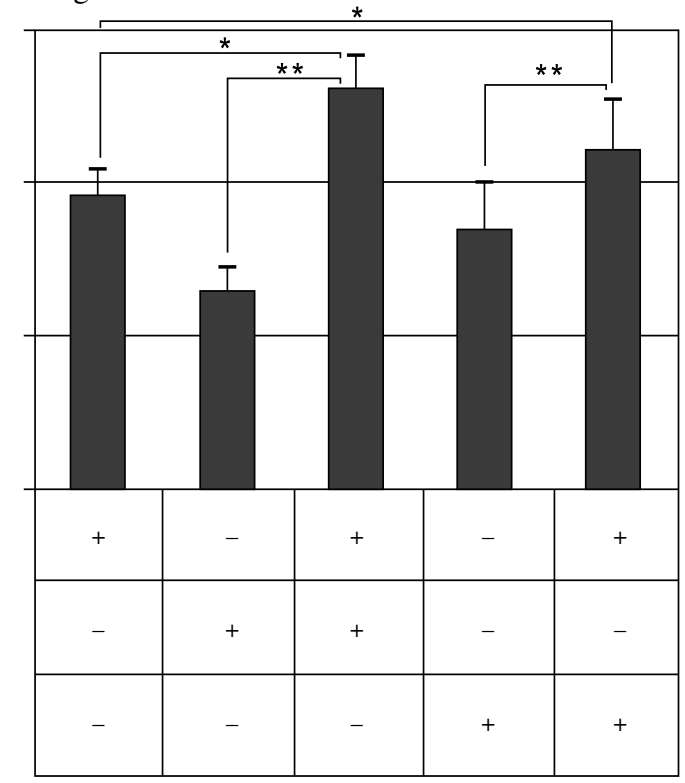

$* p<0.05, * * p<0.01$

Fig. 4. CysLT synthesis and release from (A) native, IgE-uncoated mast cells or (B) IgE-coated mast cells in response to simultaneous stimulation with TLR ligand and anti-IgE. LAM was used at final concentration of $2.5 \mu \mathrm{g} / \mathrm{ml}$ and LPS was used at final concentration of $0.5 \mu \mathrm{g} / \mathrm{ml}$. Results are presented as the mean \pm SEM of three independent experiments and each experiment was carried out in duplicate $(n=6)$

and anti-IgE also interacted synergistically in promoting cysLT synthesis by IgE-coated mast cells. We noticed, however, that LAM was more effective in augmenting production of cysLTs than LPS. CysLT synthesis increased up to $201 \%$ (as compared with LAM-induced cysLT generation) and up to $136 \%$ (as compared with anti-IgE-mediated cysLT generation) after co-stimulation with LAM and anti-IgE, and up to $130 \%$ and $115 \%$ (as compared with LPS-induced and anti-IgE-mediated cysLT generation, respectively) (Fig. 4B). What is more, the synergistic effect of stimulation with TLR ligands and anti-IgE on cysLT synthesis was more obvious in IgE-coated mast cells than in native mast cells.

\section{Discussion}

In the present study we demonstrated that subsequent or simultaneous mast cell stimulation via TLR and FceRI may influence mast cell activity. However, this effect seemed to be dependent on the kind of TLR and FceRI/IgE complex formation, as well. We established that TLR4 ligation mediated by LPS priming did not modify degranulation and histamine release from native as well as IgE-coated mast cells following FceRI cross-linking. Under the same experimental conditions LAM-induced TLR2 ligation caused statistically significant $(p<0.01)$ decrease in FceRImediated histamine release from IgE-coated mast cells. What is more, simultaneous stimulation via TLR4 or TLR2 and FceRI resulted in synergistic amplification of cysLT generation from IgE-coated mast cells and, to a lesser extent, from native mast cells.

The data available so far, concerning the effect of TLR2 or TLR4 ligation on FceRI-dependent mast cell response, are sparse. It should be emphasized that the majority of research were carried out only on mast cell lines coated in vitro with IgE. It has been established that TLR2 ligands, i.e. peptidoglycan (PGN) and lipoteichoic acid (LTA), reduced FceRI-mediated degranulation of human mast cell line LAD2, and only LTA-priming significantly inhibited FceRI-dependent degranulation of human pulmonary mast cells, as assessed by $\beta$-hexosaminidase release [22]. It was also stated that there was no significant change in degranulation of bone marrow-derived mast cells (BMMCs) following stimulation through TLR4 with LPS and FceRI cross-linking [23]. Substantial enhancement of FceRI-mediated degranulation of connective as well as mucosal like mast cells was noticed after prolonged exposure (up to $96 \mathrm{~h}$ ) to LPS. Under the same experimental conditions amplified secretion of cysLT was observed [24]. Moon et al. [25] established that TLR4 ligation induced by LPS caused significant increase in IgE-dependent prostaglandin (PG) $\mathrm{D}_{2}$ generation from BMMC. On the contrary, some data clearly demonstrated no influence of LPS stimulation on mast cell arachidonic acid metabolite synthesis following FceRI aggregation $[17,26]$. Interestingly, it was documented that 
the combination of TLR2 or TLR4 stimulation and FceRI cross-linking resulted in synergistically amplified secretion of many, especially Th2-skewed, cytokines and chemokines from mast cells [14, 23, 26-28].

The underlying mechanisms by which TLR ligands in combination with FceRI-mediated activation influence mast cell response remain unclear. TLR2 and TLR4 agonists may modulate the surface expression of FceRI and in consequence can alter mast cell FceRI-dependent response [17, $22,29]$. Since it is well documented that TLR ligation stimulates mast cell to various cytokine secretion [5, 7, 14-17] it may be assumed that these secreted cytokines indirectly affect FceRI-dependent mast cell activity by autocrine feedback loop mechanism [22, 23, 25]. Little is known about impact of mast cell stimulation mediated via both TLR- and FceRI-dependent pathway on intracellular signaling events. On the one hand, mast cell co-treatment through both FceRI and TLR2 or TLR4 receptors resulted in the attenuation of mitogen activated protein kinase (MAPK) phosphorylation $[23,30]$ as well as in suppression of intracellular calcium mobilization with no change in calcium influx [26, 30, 31]. On the other hand, Qiao et al. [26] observed the synergistic enhancement of the MAP kinases (p38, JNK) and transcriptional factors phosphorylation (ATF-2, c-Jun, c-Fos) after mast cell activation via TLR2 or TLR4 and FceRI. An intriguing observation was made by Mertsching et al. [32] that mast cell response to LPS and FceRI aggregation, which resulted in synergistic increase of cytokine secretion, may be regulated via inhibitory receptor FceRIIB.

In the course of our study we also demonstrated that native mast cells isolated from rat peritoneal cavity and cells that were coated in vitro with IgE may respond differently to sequential/simultaneous TLR ligation and FceRI crosslinking. There is a compelling evidence that $\operatorname{IgE}$ alone augments cell surface expression of FceRI on mast cells. The main mechanism of this upregulation involves IgE-induced stabilization and accumulation of receptors at the plasma membrane and, in consequence, lower FceRI internalization and degradation [18-21]. This phenomenon might be partially implicated in different response to TLR- and FceRI-mediated activation of IgE-coated in comparison with native mast cells observed in our study.

In summary, more and more data indicate that putative cross-talk between TLR- and FceRI-dependent stimulation modulates mast cell response. Since mast cells are regarded to be a crucial effector cells in allergic processes $[1,2]$ further research in this field may provide us with better understanding of mechanistic basis for allergic disease exacerbation upon coexisting infections.

This work was supported by Medical University of Łódź (Grant 502-03/6-164-01/502-64-037).

The authors declare no conflict of interest.

\section{References}

1. Reuter S, Stassen M, Taube C (2010): Mast cells in allergic asthma and beyond. Yonsei Med J 51: 797-807.

2. Bradding P, Walls AF, Holgate ST (2006): The role of mast cell in the pathophysiology of asthma. J Allergy Clin Immunol 117: $1227-1284$

3. Brzezińska-Błaszczyk E, Wierzbicki M (2010): Mast cell Tolllike receptors (TLRs). Postepy Hig Med Dosw 64: 11-21.

4. Oleś D, Szczepankiewicz A (2012): Role of Toll-like receptors in the development of allergic inflammation in asthma. Postep Derm Alergol 29: 275-278.

5. Mrabet-Dahbi S, Metz M, Dudeck A, et al. (2009): Murine mast cells secrete a unique profile of cytokines and prostaglandins in response to distinct TLR2 ligands. Exp Dermatol 18: 437-444.

6. Ikeda T, Funaba M (2003): Altered function of murine mast cells in response to lipopolysaccharide and peptidoglycan. Immunol Lett 88: 21-26.

7. McCurdy JD, Olynych TJ, Maher LH, Marshall JS (2003): Cutting edge: Distinct Toll-like receptor 2 activators selectively induce different classes of mediator production from human mast cells. J Immunol 170: 1625-1629.

8. Wierzbicki M, Brzezińska-Błaszczyk E (2009): Diverse effects of bacterial cell wall components on mast cell degranulation, cysteinyl leukotriene generation and migration. Microbiol Immunol 53: 694-703.

9. Konopka Ł, Wierzbicki M, Brzezińska-Błaszczyk E (2010): Lipopolysaccharide from Porphyromonas gingivalis stimulates rat mast cells to cysteinyl leukotriene generation and upregulates Toll-like receptor -2 and -4 expression. Int J Immunopathol Pharmacol 23: 803-810.

10. Brzezińska-Błaszczyk E, Rdzany RS (2007): Lipoteichoic acids selectively stimulate rat mast cells to cysteinyl leukotriene generation and affect mast cell migration after tumor necrosis factor (TNF)-priming. Immunol Lett 109: 138-144.

11. Kikawada E, Bonventre JV, Arm JP (2007): Group V secretory PLA2 regulates TLR2-dependent eicosanoid generation in mouse mast cells through amplification of ERK and cPLA2alpha activation. Blood 110: 561-567.

12. Pietrzak A, Wierzbicki M, Wiktorska M, Brzezińska-Błaszczyk E (2011): Surface TLR2 and TLR4 expression on mature rat mast cells can be affected by some bacterial components and proinflammatory cytokines. Mediators Inflamm 2011: 1-11.

13. Bąbolewska E, Witczak P, Pietrzak A, Brzezińska-Błaszczyk E (2012): Different potency of bacterial antigens TLR2 and TLR4 ligands in stimulating mature mast cells to cysteinyl leukotriene synthesis. Microbiol Immunol 56: 183-190.

14. Masuda A, Yoshikai Y, Aiba K, Matsuguchi T (2002): Th2 cytokine production from mast cells is directly induced by lipopolysaccharide and distinctly regulated by c-Jun N-terminal kinase and p38 pathways. J Immunol 169: 3801-3810.

15. Supajatura V, Ushio H, Nakao A, et al. (2002): Differential responses of mast cell Toll-like receptors 2 and 4 in allergy and innate immunity. J Clin Invest 109: 1351-1359.

16. Supajatura V, Ushio H, Nakao A, et al. (2001): Protective roles of mast cells against enterobacterial infection are mediated by Toll-like receptor 4. J Immunol 167: 2250-2256.

17. Kirshenbaum AS, Swindle E, Kulka M, et al. (2008): Effect of lipopolysaccharide (LPS) and peptidoglycan (PGN) on human mast cell numbers, cytokine production, and protease composition. BMC Immunol 9: 45.

18. Kubo S, Matsuoka K, Taya C, et al. (2001): Drastic up-regulation of FceRI on mast cells is induced by IgE binding through 
stabilization and accumulation of FceRI on the cell surface. J Immunol 167: 3427-3434.

19. Borkowski TA, Jouvin MH, Lin SY, Kinet JP (2001): Minimal requirements for IgE-mediated regulation of surface FceRI. J Immunol 167: 1290-1296.

20. Kashiwakura J, Otani IM, Kawakami T (2011): Monomeric $\mathrm{IgE}$ and mast cell development, survival and function. Adv Exp Med Biol 716: 29-46.

21. Bax HJ, Keeble AH, Gould HJ (2012): Cytokinergic IgE action in mast cell activation. Front Immunol 3: 229.

22. Yoshioka M, Fukuishi N, Iriguchi S, et al. (2007): Lipoteichoic acid downregulates FceRI expression on human mast cells through Toll-like receptor 2. J Allergy Clin Immunol 120: 452-461.

23. Saturnino SF, Prado RO, Cunha-Melo JR, Andrade MV (2010): Endotoxin tolerance and cross-tolerance in mast cells involves TLR4, TLR2 and FceRI interactions and SOCS expression: perspectives on immunomodulation in infectious and allergic diseases. BMC Infect Dis 10: 240.

24. Saluja R, Delin I, Nilsson GP, Adner M (2012): FceRI-mediated mast cell reactivity is amplified through prolonged Tolllike receptor-ligand treatment. PLoS One 7: e43547.

25. Moon TC, Murakami M, Ashraf MD, et al. (1998): Regulation of cyclooxygenase- 2 and endogenous cytokine expression by bacterial lipopolysaccharide that acts in synergy with c-kit ligand and Fce receptor I crosslinking in cultured mast cells. Cell Immunol 185: 146-152.

26. Qiao H, Andrade MV, Lisboa FA, et al. (2006): FceRI and tolllike receptors mediate synergistic signals to markedly augment production of inflammatory cytokines in murine mast cells. Blood 107: 610-618.

27. Nigo YI, Yamashita M, Hirahara K, et al. (2006): Regulation of allergic airway inflammation through Toll-like receptor 4-mediated modification of mast cell function. Proc Natl Acad Sci U S A 103: 2286-2291.

28. Stassen M, Müller C, Arnold M, et al. (2001): IL-9 and IL-13 production by activated mast cells is strongly enhanced in the presence of lipopolysaccharide: NF- $\mathrm{BB}$ is decisively involved in the expression of IL-9. J Immunol 166: 4391-4398.

29. Kawahara T (2010): Inhibitory effect of heat-killed Lactobacillus strain on immunoglobulin E-mediated degranulation and late-phase immune reactions of mouse bone marrowderived mast cells. Anim Sci J 81: 714-721.

30. Kasakura K, Takahashi K, Aizawa T, et al. (2009): A TLR2 ligand suppresses allergic inflammatory reactions by acting directly on mast cells. Int Arch Allergy Immunol 150: 359-369.

31. Fehrenbach K, Port F, Grochowy G, et al. (2007): Stimulation of mast cells via FceRI and TLR2: the type of ligand determines the outcome. Mol Immunol 44: 2087-2094.

32. Mertsching E, Bafetti L, Hess H, et al. (2008): A mouse FceFce protein that inhibits mast cells through activation of FceRIIB, SH2 domain-containing inositol phosphatase 1, and SH2 domain-containing protein tyrosine phosphatases. J Allergy Clin Immunol 121: 441-447. 